\title{
ASSESSMENT OF AIR POLLUTION TOLERANCE INDEX OF PLANTS: A COMPARATIVE STUDY
}

\author{
AASAWARI A. TAKa, UMESH B. KAKDE ${ }^{*}$ \\ aDepartment of Botany, The Institute of Science, 15, Madame Cama Road, Fort, Mumbai 400032, Maharashtra, India \\ Email: drumeshkakde@gmail.com
}

Received: 13 Mar 2017 Revised and Accepted: 19 May 2017

\begin{abstract}
Objective: Air pollution is one of the major global tribulations in many developing cities around the world. Addressing this sort of pollution is more intricate than other ecological challenges. As pollution is an upcoming issue, we aimed at assessing the air pollution tolerant plants from roadside exposed to vehicular air pollution from two different locations in Thane city.

Methods: In the present study, commonly available ten roadside tree species selected from polluted and control area, and their air pollution tolerance index (APTI) determined in Thane city. The biochemical parameters viz. pH, ascorbic acid, total chlorophyll, relative water content (RWC) were considered to calculate APTI by using standard method.

Results: The study shows that the control site has more APTI than the polluted site. The APTI observed minimum in Tectona grandis $5.2 \pm 0.3247$ and maximum in Azadirachta indica 13.5 \pm 0.4404 . Reduction in APTI at polluted site shows that Alstonia scholaris (6.6\%), Tamarindus indica (8.8\%) and Azadirachta indica (10.3\%) were the most tolerant tree species, while Tectona grandis (47.5\%), Acacia nilotica (27.4\%) and Cassia fistula (20.7\%) were more sensitive tree species. The results showed the order of tolerance (\% difference in APTI) as Alstonia scholaris (6.6\%) >Tamarindus indica (8.8\%) >Azadirachta indica (10.3\%)>Moringa pterygosperma (11.9\%) >Mangifera indica (13.9\%) >Bahunia variegate (14.3\%) >Annona squamosa $(18.7 \%)>$ Cassia fistula (20.7\%)>Acacia nilotica (27.4\%) >Tectona grandis (47.5\%).
\end{abstract}

Conclusion: Tolerant trees species can serve as a sink, and sensitive tree species can act as an indicator for air pollution mitigation. Thus, this study provides useful insights for selecting tolerant species for future planning and Greenbelt development in urban areas.

Keywords: Ascorbic acid, Chlorophyll, Relative water content, pH, Air pollution tolerance index, Greenbelt, Air pollution

(C) 2017 The Authors. Published by Innovare Academic Sciences Pvt Ltd. This is an open access article under the CC BY license (http://creativecommons.org/licenses/by/4.0/) DOI: http://dx.doi.org/10.22159/ijpps.2017v9i7.18447

\section{INTRODUCTION}

Pollution is an upcoming issue, which alters metabolism in any organisms. The rapid growth of industries and vehicular density is the primary cause behind the rise in environmental air pollution in urban areas and is a major problem of cities [1]. The expanding cities in developing countries are at the receiving end as they face the wrath of air pollution. Vehicular exhaust and construction work are the primary reasons for air pollution in the city. Continuous increase in vehicles is adding further vows. Trees are playing a major role in improving air quality by exchanging gases as they act as a sink for the air pollutants. They remove particulate matter by acting as living filters to minimize the air pollution. Trees that exposed to environmental pollutants absorb, accumulate and integrate these pollutants into their systems, depending on their sensitivity level. Plants show visible damages, which would include alteration of the biochemical processes or accumulation of individual metabolites. These changes used for assessing the APTI of plants [2].

Many researchers have investigated air pollutants through plants when exposed to air pollution [3-6]. Most plant experiences physiological changes before exhibiting visible damage to leaves [7]. According to responses of plants towards air pollution, analysis of some biological parameters of each species helps in determining tolerance level. The impacts of air pollution on ascorbic acid content [8], chlorophyll content [9], and leaf extract pH [10] and RWC [11] has extensively studied. In the present study, four parameters (ascorbic acid, total chlorophyll content, relative water content and leaf extract $\mathrm{pH}$ ) analyzed and expressed together in one formula to evaluate the sensitivity of plants to air pollutants [12]. APTI determines the plant's reaction to air pollution and the plant's ability to fight against air pollution [13].

There is no distinct barrier between industrial and residential areas due to rapid urbanization in developing countries. Due to this, deterioration of air quality is the major environmental problem in urban areas. Air pollution in urban areas is adversely affecting human health, and it is affecting plant's life enormously, which is difficult to quantify. Each plant species tends to respond differently to different pollutants and climatic conditions. Therefore, the present study was carried out to understand the resistance and adaptability of plants towards air pollution.

In the current study, the susceptibility levels of commonly growing tree species on the roadside exposed to vehicular air pollution have been determined based on their air pollution tolerance indices. Biological monitoring of plant tolerance towards air pollution helps in selecting tolerant and sensitive plants as a bioindicator of air pollution. The plants with the minimum tolerance index value were sensitive to air pollution. While the plants with high tolerance index value were tolerant to air pollution. Tolerant species helps in mitigating air pollution while less tolerant species acts as an indicator. Greenbelt developers can employ results of the study in managing the urban air pollution.

\section{MATERIALS AND METHODS}

Chemicals and reagent used

All chemicals and reagents were of analytical grade. Acetone, magnesium carbonate, oxalic acid, distilled water, standard $\mathrm{pH}$ solution (buffer) were obtained from the department of botany, Institute of Science, Mumbai. Ethylenediaminetetraacetic acid (EDTA), metaphosphoric acid pellets, acetic acid, ammonium molybdate, sulphuric acid, standard L-ascorbic acid were purchased from Paras Chem India, (Mumbai).

\section{Study area and sampling location}

Thane city is located in Maharashtra State and is a part of the Mumbai metropolitan region. Thane city lies between $19^{\circ} 12^{\prime} \mathrm{N}$ and $73^{\circ} 02^{\prime} \mathrm{E}$ and spread over the area of 128.23 square $\mathrm{km}$. The maximum temperature ranges from $35{ }^{\circ} \mathrm{C}$ to $40{ }^{\circ} \mathrm{C}$ during summer, and the minimum temperature is between $25^{\circ} \mathrm{C}$ to $35^{\circ} \mathrm{C}$ during the winter months of November-January. The average rainfall is about 
$2500 \mathrm{~mm}$ receives during the rainy season from June to the end of September. The climate of the region is coastal, hot and humid.

Sampling sites are located in Thane city. Chendani Koliwada area in Thane with high peak hour vehicular traffic volume selected as the polluted site $(\mathrm{P})$. The area with a dense forest of Yeoor hills near the city chosen as the control site (C).

\section{Collection of plant material}

Fresh leaves from each plant were collected from both the sites (control and polluted). The present work was designed to assess the effects of air pollution on plants; hence, 10 commonly available plants exposed to vehicular emission along the roadside were selected for the study (viz., Alstonia scholaris, Tamarindus indica, Azadirachta indica, Moringa pterygosperma, Mangifera indica, Bahunia variegate, Annona squamosa, Cassia fistula, Acacia nilotica, Tectona grandis). All selected plants were identified with the help of available standard literature (14) and verified with the help of experts in the field of taxonomy. Three samples from healthy and fully matured leaves of each plant gathered through the random selection from the lowermost position of a canopy at the height of 1.8-2.1 m from ground level. The further analysis was carried out in the laboratory. All collected leaf samples were washed with the running tap water, rinsed with distilled water and then used for further analysis.

\section{Estimation of total chlorophyll}

$1.0 \mathrm{~g}$ of the greenest leaves were selected and cleaned thoroughly with water and dried at room temperature for a while. Then samples were macerated in a pestle with mortar by adding $20-25 \mathrm{ml}$ of $80 \%$ acetone. A pinch of magnesium carbonate was added to the material prior to extraction to prevent deterioration of chlorophyll. The leaf extract content was centrifuged at $2000 \mathrm{r}$. p. m. for $15 \mathrm{~min}$ in the cooling centrifuge. Transferred the extract to a volumetric flask and made to the volume of $50 \mathrm{ml}$ using $80 \%$ acetone. The optical density of this green solution read at $645 \mathrm{~nm}$ (D645), and $663 \mathrm{~nm}$ (D663) using a spectrophotometer and the total chlorophyll calculated with the following formula by Arnon [15].

$$
\mathrm{CT}=20.2(\mathrm{D} 645) \pm 8.02(\mathrm{D} 663)
$$

\section{Measuring leaf extract $\mathrm{pH}$}

$\mathrm{pH}$ is the measure of hydrogen ion activity and mostly depends on the relative amounts of the adsorbed hydrogen and metallic ions. It is a good measure of the intensity of acidity and alkalinity of suspension. $5.0 \mathrm{~g}$ of fresh leaves were homogenized in $10 \mathrm{ml}$ distilled water. Leaf extract filtered and the $\mathrm{pH}$ determined after calibrating $\mathrm{pH}$ meter with a buffer solution of $\mathrm{pH} 4,7$ and 9 .

\section{Relative water content (RWC)}

Fresh weight obtained by weighing the fresh leaves. The leaves were then immersed overnight in water blotted, dry and then weighed to get the turgid weight. The leaves kept to dry overnight in an oven at 70 ${ }^{\circ} \mathrm{C}$ and reweighed to obtain the dry weight. RWC was determined and calculated by the following formula by Barr and Weatherly [16].

$$
\text { RWC }(\%)=[(F W-D W)] /[(T W-D W)] \times 100
$$

Where,

FW is Fresh weight,

DW is Dry weight, and

TW is turgid weight.

\section{Ascorbic acid analysis}

$1.0 \mathrm{~g}$ of fresh foliage homogenized in $4.0 \mathrm{ml}$ oxalic acid-EDTA extracting solution for the $30 \mathrm{~s} .0 .5 \mathrm{ml}$ of metaphosphoric acid-acetic acid and $1.0 \mathrm{ml}$ of $5 \% \mathrm{v} / \mathrm{v}$ sulphuric acid followed by $2.0 \mathrm{ml}$ of ammonium moly date and dilute with distilled water. The solution was kept to stand for $15 \mathrm{~min}$. The absorbance was read off with a digital spectrophotometer at 760 $\mathrm{nm}$. The concentration of the ascorbic acid determined from a standard ascorbic acid regression curve by Bajaj and Kaur [17].

\section{Air pollution tolerance index (APTI) determination}

The air pollution tolerance indices often commonly available plants were determined by the following method by Singh and Rao [18].

$$
\mathrm{APTI}=[\mathrm{A} \times(\mathrm{T} \pm \mathrm{P}) \pm \mathrm{R}] /[10]
$$

Where, A is Ascorbic acid (mg/g fr. wt),

$\mathrm{T}$ is Total chlorophyll ( $\mathrm{mg} / \mathrm{g}$ fr. $\mathrm{wt}$ ),

$\mathrm{P}$ is Leaf extracts $\mathrm{pH}$ and

$\mathrm{R}$ is Relative water content (RWC) [(\%) of the leaves].

\begin{tabular}{|c|c|c|c|c|c|c|c|c|c|}
\hline $\begin{array}{l}\text { S. } \\
\text { No. }\end{array}$ & $\begin{array}{l}\text { Botanical } \\
\text { name }\end{array}$ & Site & $\begin{array}{l}\text { Total } \\
\text { chlorophyll } \\
\text { (mg/g) }\end{array}$ & $\begin{array}{l}\text { pH of leaf } \\
\text { extract }\end{array}$ & $\begin{array}{l}\text { Relative water } \\
\text { content (RWC) } \\
(\%)\end{array}$ & $\begin{array}{l}\text { Ascorbic } \\
\text { acid } \\
(\mathrm{mg} / \mathrm{g})\end{array}$ & APTI & $\begin{array}{l}\text { Difference } \\
\text { in APTI }\end{array}$ & $\begin{array}{l}\text { \% difference } \\
\text { in APTI }\end{array}$ \\
\hline \multirow[t]{2}{*}{1} & Moringa & $C$ & $3.2 \pm 0.0237$ & $5.4 \pm 0.0$ & $69.2 \pm 0.1732$ & $10.6 \pm 0.4$ & $16 \pm 0.3363$ & 3.4 & 11.9 \\
\hline & pterygosperma & $P$ & $2.7 \pm 0.0105$ & $5.9 \pm 0.0$ & $55.4 \pm 0.05$ & $6.1 \pm 0.557$ & $12.6 \pm 0.2168$ & & \\
\hline \multirow[t]{2}{*}{2} & Tamarindus & $C$ & $5.9 \pm 0.0265$ & $3.1 \pm 0.0$ & $70.4 \pm 1.015$ & $4.5 \pm 0.3214$ & $11.1 \pm 0.3139$ & 1.8 & 8.8 \\
\hline & indica & $P$ & $4.9 \pm 0.0311$ & $2.9 \pm 0.0$ & $65.3 \pm 0.1732$ & $3.6 \pm 0.4$ & $9.3 \pm 0.3054$ & & \\
\hline \multirow[t]{2}{*}{3} & Tectona & C & $4.7 \pm 0.0194$ & $5.3 \pm 0.0$ & $44.1 \pm 4.063$ & $10.2 \pm 0.7$ & $14.6 \pm 0.3036$ & 9.4 & 47.5 \\
\hline & grandis & $P$ & $3.5 \pm 0.0451$ & $6.3 \pm 0.0$ & $37.3 \pm 2.265$ & $1.5 \pm 0.4582$ & $5.2 \pm 0.3247$ & & \\
\hline \multirow[t]{2}{*}{4} & Annona & $C$ & $1.8 \pm 0.0231$ & $6.0 \pm 0.0$ & $49.9 \pm 4.942$ & $7.8 \pm 0.5568$ & $11.1 \pm 0.1836$ & 3.5 & 18.7 \\
\hline & squamosa & $P$ & $1.6 \pm 0.0116$ & $6.5 \pm 0.0$ & $38.7 \pm 1.852$ & $4.6 \pm 0.4582$ & $7.6 \pm 0.2327$ & & \\
\hline \multirow[t]{2}{*}{5} & Azadirachta & C & $3.7 \pm 0.0208$ & $6.3 \pm 0.0$ & $74.2 \pm 5.568$ & $9.1 \pm 0.3605$ & $16.6 \pm 0.1819$ & 3.1 & 10.3 \\
\hline & indica & $P$ & $2.2 \pm 0.0529$ & $5.9 \pm 0.0$ & $67.5 \pm 1.179$ & $8.2 \pm 0.3605$ & $13.5 \pm 0.4404$ & & \\
\hline \multirow[t]{2}{*}{6} & Acacia nilotica & C & $7.8 \pm 0.0208$ & $5.2 \pm 0.0$ & $81.3 \pm 8.168$ & $1.5 \pm 0.1732$ & $10.0 \pm 0.6850$ & 4.3 & 27.4 \\
\hline & & $P$ & $5.1 \pm 0.0866$ & $5.7 \pm 0.0$ & $47.1 \pm 6.219$ & $0.9 \pm 0.1$ & $5.7 \pm 0.7050$ & & \\
\hline \multirow[t]{2}{*}{7} & Mangifera & $C$ & $3.3 \pm 0.1$ & $6.2 \pm 0.0$ & $92.9 \pm 6.784$ & $7.9 \pm 0.6557$ & $16.8 \pm 0.2475$ & 4.1 & 13.9 \\
\hline & indica & $P$ & $2.5 \pm 0.138$ & $6.2 \pm 0.0$ & $73.3 \pm 2.858$ & $6.1 \pm 0.557$ & $12.7 \pm 0.2799$ & & \\
\hline \multirow[t]{2}{*}{8} & Cassia fistula & C & $5 \pm 0.0866$ & $6.2 \pm 0.0$ & $78.4 \pm 10.001$ & $8.9 \pm 0.2645$ & $17.8 \pm 0.9324$ & 6.1 & 20.7 \\
\hline & & $P$ & $4.1 \pm 0.1732$ & $6.6 \pm 0.0$ & $56.5 \pm 7.549$ & $5.7 \pm 0.1732$ & $11.7 \pm 0.9136$ & & \\
\hline \multirow[t]{2}{*}{9} & Alstonia & $C$ & $4.4 \pm 0.1322$ & $6.0 \pm 0.0$ & $92.2 \pm 3.477$ & $3.7 \pm 0.1$ & $13 \pm 0.2566$ & 1.6 & 6.6 \\
\hline & scholaris & $P$ & $2.4 \pm 0.05$ & $5.8 \pm 0.0$ & $86.1 \pm 0.8544$ & $3.4 \pm 0.1732$ & $11.4 \pm 0.0897$ & & \\
\hline \multirow[t]{2}{*}{10} & Bahunia & $C$ & $3.4 \pm 0.1732$ & $6.7 \pm 0.0$ & $74.4 \pm 4.582$ & $5.3 \pm 0.1$ & $12.8 \pm 0.3480$ & 3.2 & 14.3 \\
\hline & variegate & $P$ & $1.6 \pm 0.05$ & $6.7 \pm 0.0$ & $63.7 \pm 3.606$ & $3.8 \pm 0.1732$ & $9.6 \pm 0.2184$ & & \\
\hline
\end{tabular}

The APTI values help to identify the tolerant and sensitive plant species.

Table 1: The APTI of selected plant species at the control and the polluted site

Note: Mean \pm SEM for triplicates of plants showing the values for the biochemical parameters 


\section{Statistical analysis}

The evaluation of plant material was done in triplicates. The correlation coefficient was determined between independent variables viz. total chlorophyll, pH, RWC, ascorbic acid and dependent variable such as APTI. To determine the degree of correlation between the variables Analysis ToolPack in Excel was used. Results were expressed as graphs representing mean \pm SEM (Standard error of mean)

\section{RESULTS}

The results of APTI presented in table 1.

\section{Total chlorophyll}

Results of total chlorophyll presented in table 1 . Total chlorophyll found the maximum $5.1 \pm 0.0866 \mathrm{mg} / \mathrm{g}$ in Acacia nilotica and the minimum $1.6 \pm 0.0116 \mathrm{mg} / \mathrm{g}$ in Annona squamosa. The study revealed that total chlorophyll decreased significantly in plant leaves at the polluted area as compared to the control area. Reduction in chlorophyll content observed the minimum for Annona squamosa (5.9\%), followed by Moringa pterygosperma (8.5\%) and Tamarindus indica (9.3\%). Reduction in chlorophyll content found the maximum for Bahunia variegata (36.0\%), followed by Alstonia scholaris (29.4\%) and Azadirachta indica (25.4\%).

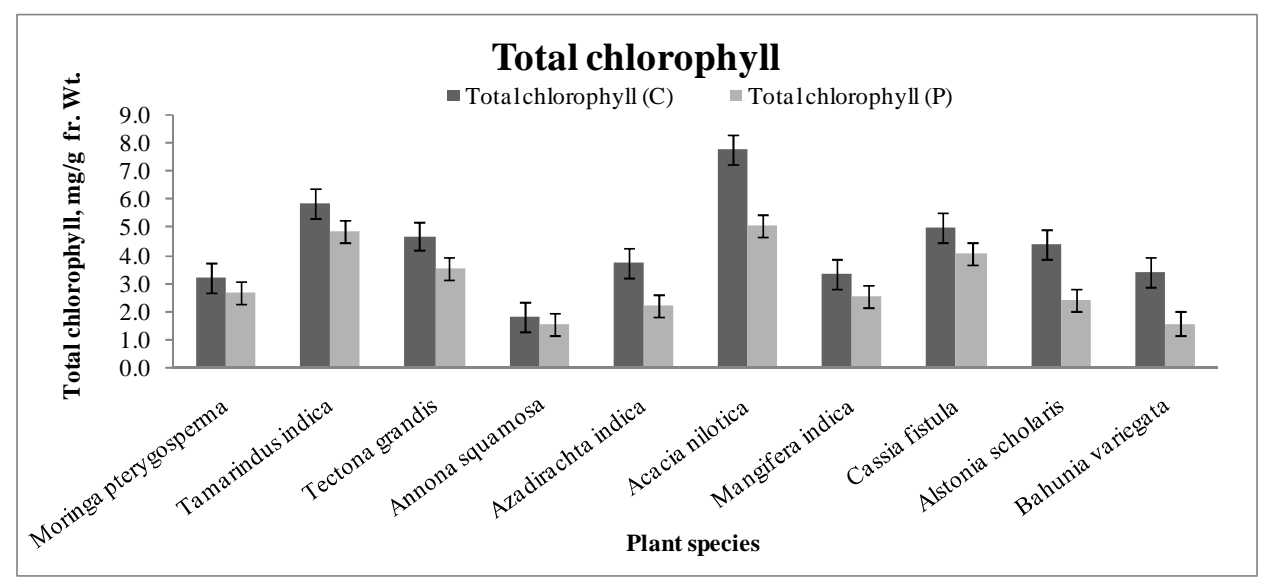

Fig. 1: Total chlorophyll content of plant species at the control and the polluted sites

Note Total chlorophyll (C)-Total chlorophyll at the control site, Total chlorophyll (P)-Total chlorophyll at the polluted site. Values are expressed as mean \pm SEM, and the analysis was done in triplicates

\section{Ascorbic acid}

Results of ascorbic acid presented in fig. 2. The ascorbic acid content found the maximum in Azadirachta indica $8.2 \pm 0.3605 \mathrm{mg} / \mathrm{g}$ fr. wt. While the minimum in Acacia nilotica $0.9 \pm 0.1 \mathrm{mg} / \mathrm{g}$ fr. wt. Plants were maintaining high ascorbic acid under pollutant conditions considered as tolerant to air pollution. The study revealed that ascorbic acid decreased significantly in plant leaves at the polluted area as compared to the control area. Reduction in ascorbic acid content found the minimum for Alstonia scholaris (4.2\%), followed by Azadirachta indica (5.2\%) and Tamarindus indica (11.1\%). Reduction in ascorbic acid content observed the maximum for Tectona grandis $(74.4 \%)$, followed by Annona squamosa (25.8\%) and Acacia nilotica (25.0\%).

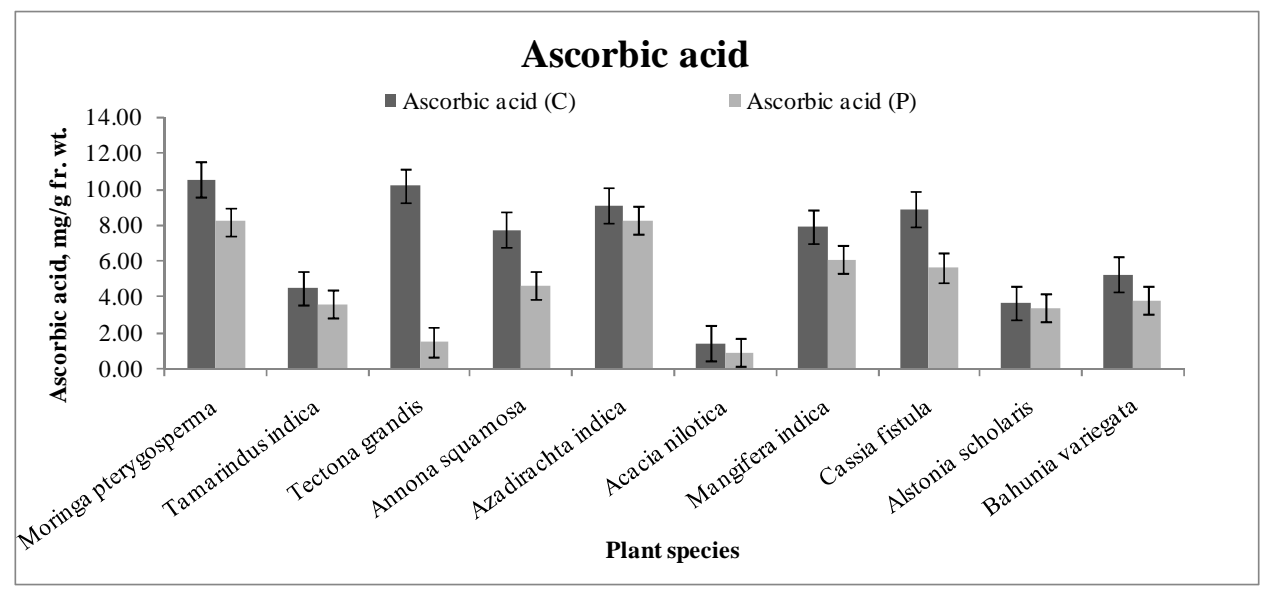

Fig. 2: Ascorbic acid content of plant species at the control and the polluted sites

Note Ascorbic acid (C)-Ascorbic acid at the control site, Ascorbic acid (P)-Ascorbic acid at the polluted site. Values are expressed as mean \pm SEM and the experiments were done in triplicates.

\section{Leaf extract $\mathrm{pH}$}

The leaf extract $\mathrm{pH}$ found the maximum $6.7 \pm 0.0$ in Bahunia variegata, and the minimum in Tamarindus indica $2.9 \pm 0.0$. The leaf extract $\mathrm{pH}$ plays a major role in regulating the $\mathrm{SO}_{2}$ sensitivity of plants. The change observed in leaf extract $\mathrm{pH}$ observed the minimum for Bahunia variegata $(0.0 \%)$, followed by Mangifera indica $(0.0 \%)$ and Alstonia scholaris $(1.7 \%)$. The change observed in leaf extract $\mathrm{pH}$ found the maximum for Tectona grandis $(8.6 \%)$, followed by Moringa pterygosperma (4.4\%) and Acacia nilotica (4.6\%). Results of leaf extract $\mathrm{pH}$ shown in fig. 3. 


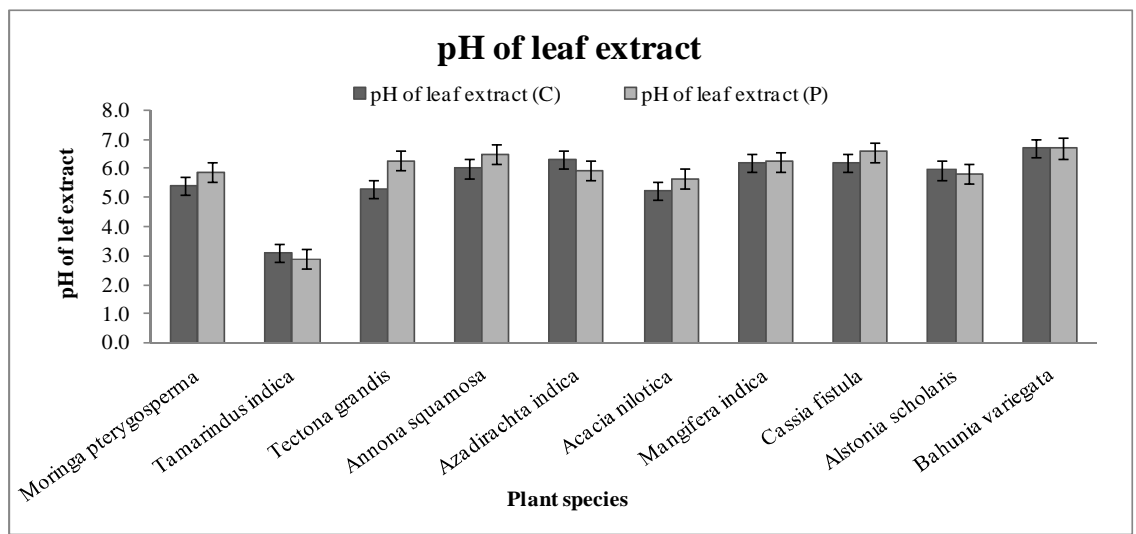

Fig. 3: pH of leaf extract for plant species at the control and the polluted sites

Note: $\mathrm{pH}$ of leaf extract (C)-pH of leaf extract at the control site, $\mathrm{pH}$ of leaf extract (P)-pH of leaf extract at the polluted site. Values are expressed as mean \pm SEM and the analysis was done in triplicates.

\section{Relative water content (RWC)}

The RWC found maximum $86.13 \pm 0.8544 \%$ in Alstonia scholaris and minimum in Tectona grandis $37.27 \pm 2.265 \%$. The study revealed that RWC decreased in plant leaves at the polluted area as compared to the control area. Results of RWC shown in fig. 4.

Reduction in RWC observed the minimum for Alstonia scholaris (3.4\%), followed by Tamarindus indica (3.8\%) and Azadirachta indica $(4.7 \%)$. Reduction in RWC found the maximum for Acacia nilotica (26.6\%), followed by Cassia fistula (16.2\%) and Annona squamosa $(12.6 \%)$.

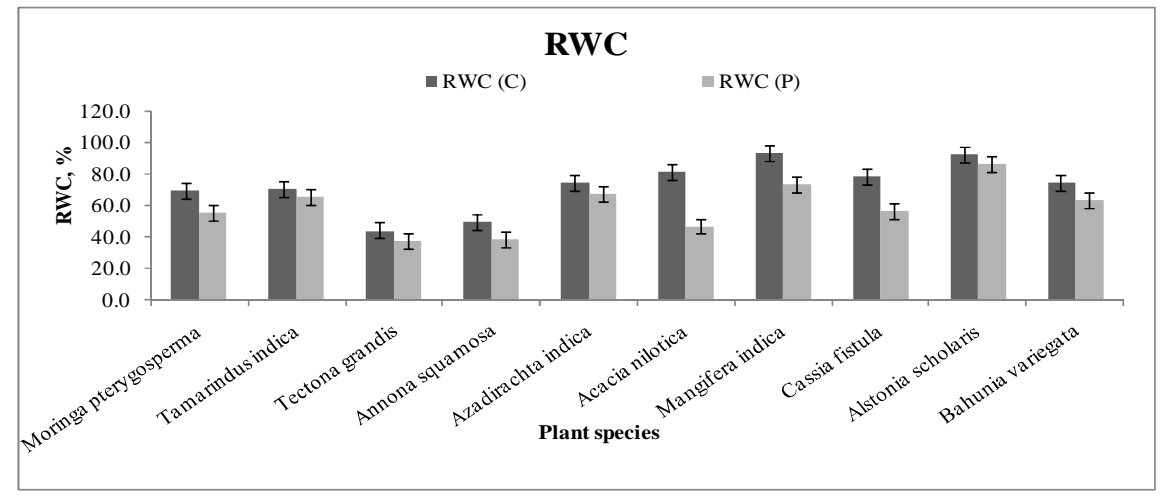

Fig. 4: Relative water content of plant species at the control and the polluted sites

Note: RWC-Relative water content, RWC(C)-Relative water content at the control site, RWC(P)-Relative water content at polluted site. Values are expressed as mean \pm SEM and the analysis was done in triplicates.

\section{Air pollution tolerance indices (APTI)}

APTI index shows the capability of a plant to fight against air pollution. The APTI found the minimum in Tectona grandis
$5.2 \pm 0.3247$ and the maximum in Azadirachta indica $13.5 \pm 0.4404$. The study reveals that the control site has more APTI than the polluted site. Reduction in APTI observed the minimum for Alstonia scholaris (6.6\%), followed by Tamarindus indica (8.8\%) and Azadirachta indica (18.7\%). Reduction in APTI found the maximum for Tectona grandis (47.5\%), followed by Acacia nilotica (27.4\%) and Cassia fistula (20.7\%). Results of APTI as shown in fig. 5.

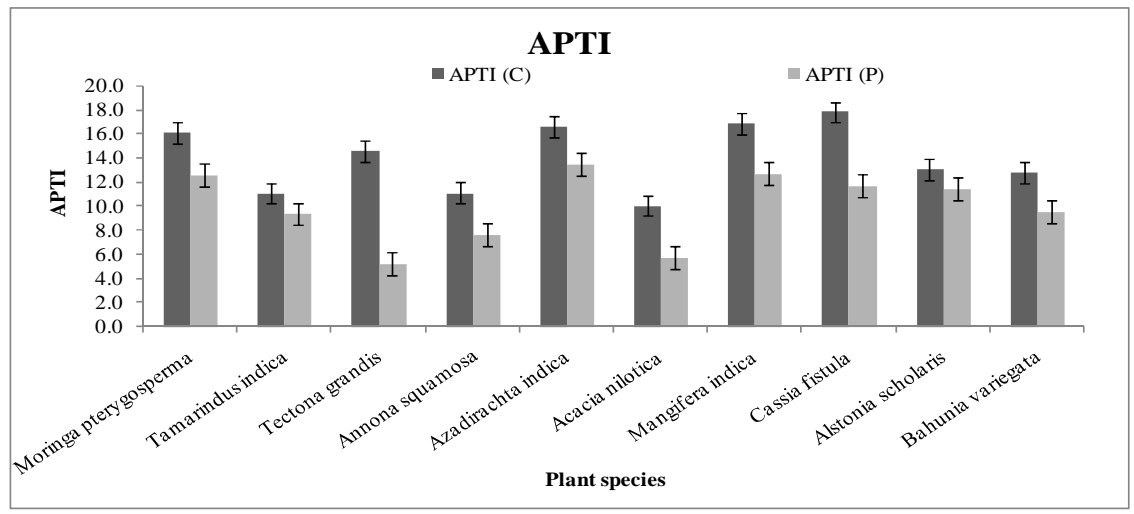

Fig. 5: APTI of plant species at the control and the polluted sites 
Note: APTI-Air pollution tolerance index, APTI (C)-APTI at the control site, APTI (P)-APTI at the polluted site. Values are expressed as mean \pm SEM, and the analysis was done in triplicates.

Table 2: Correlation between the APTI values and biochemical parameters estimated from the leaf samples of control site

\begin{tabular}{lllll}
\hline & Total chlorophyll & pH & RWC & Ascorbic acid \\
\hline Total chlorophyll & 1 & & & \\
pH & -0.515359752 & 1 & & \\
RWC & 0.248590547 & 0.198766 & 1 & \\
Ascorbic acid & -0.603916103 & 0.255081 & -0.46014 & 1 \\
APTI & -0.33886687 & 0.443226 & 0.190119 & 0.749861324 \\
\hline
\end{tabular}

Note: RWC-Relative water content, APTI-Air pollution tolerance index

Table 3: Correlation between the APTI values and biochemical parameters estimated from the leaf samples of the polluted site

\begin{tabular}{lllll}
\hline & Total chlorophyll & pH & RWC & Ascorbic acid \\
\hline Total chlorophyll & 1 & & & \\
pH & -0.569894403 & 1 & & \\
RWC & -0.192520359 & -0.22355 & 1 & \\
Ascorbic acid & -0.4498179 & 0.130612 & 0.30581 & 1 \\
APTI & -0.372470055 & 0.037882 & 0.710256 & 0.873806498 \\
\hline
\end{tabular}

Note: RWC-Relative water content, APTI-Air pollution tolerance index

\section{DISCUSSION}

Developed cities have a remarkable pressure of air pollution, which is eventually causing injuries to the plants through various means, and thus the effects of these injuries found less intolerant plant species. These tolerant plant species showed great role as bioindicators of air pollution [19].

The results showed that total chlorophyll content values found less in all selected plant species of polluted sites. It ranged from maximum $5.1 \pm 0.0866 \mathrm{mg} / \mathrm{g}$ fr. wt. in Acacia nilotica and minimum $1.6 \pm 0.0116 \mathrm{mg} / \mathrm{g}$ fr. wt. in Annona squamosa. Photosynthetic process of plant mainly depends upon the chlorophyll content and development of biomass; it varies from plant to plant due to leaf age, biotic, abiotic conditions and pollution levels [20]. The disintegration of these pigments in urbanized plants may occur due to atmospheric pollutants [21]. There are certain pollutants that increase the total chlorophyll content and others decreases. The chloroplast is the primary site of the attack by air pollutants. As the air pollutant directly enter in the tissues through stomata, cause partial denaturation of the chloroplast, and decreases the pigment content in the cells of polluted leaves. Degradation of photosynthetic pigments has been widely used as an indicator of air pollution [21]. The decrease in chlorophyll content of leaves may be due to the alkaline condition created by the dissolution of chemical present in dust particles i.e. metals and polycyclic hydrocarbons in cell sap which block the stomatal spores for diffusion of air and thus put stress on plant metabolism resulting in chlorophyll degradation [22]. Moreover, it found that pollution generated through automobiles is one of the biggest reasons in decreasing chlorophyll content in plant growing along roadsides [23, 24]. Thus, the reduction in chlorophyll content of polluted site roadside plants attributes to high levels of vehicular air pollution.

Ascorbic acid content found less in all selected plant species of the polluted site. It ranged maximum in Azadirachta indica $8.24 \pm 0.3605$ $\mathrm{mg} / \mathrm{g}$ fr. wt. and minimum in Acacia nilotica $0.93 \pm 0.1 \mathrm{mg} / \mathrm{g}$ fr. wt. Ascorbic acid acts as an antioxidant and develops the mechanism of a plant to resist against the adverse atmospheric conditions [25]. Ascorbic acid plays a role in the cell wall synthesis, defence and cell division [26]. It is also a strong reducer and plays an important role in photosynthetic carbon fixation [27]. Moreover, its high level in plants indicated high tolerance level of plant species against pollutions and its lower values rank the plants in a sensitive category against air pollution [28, 29]. Thus, the decrease in the ascorbic acid content of plant species at polluted area may be due to vehicular emissions.

The RWC found higher in all selected plant species of the polluted site. It was the maximum $86.13 \pm 0.8544 \%$ in Alstonia scholaris and the minimum $37.3 \pm 2.265 \%$ in Tectona grandis. Availability of water in plant cells associated with the protoplasmic permeability of cells and thus a loss in water content and nutrients from the cells resulted in senescence of leaf in very early stage of plant life $[30,31]$. As one study indicated that plants with higher RWC would have greater drought resistance, so it can be concluded that high water content in plants may lead the tree species as tolerant one [32]. Thus, all the results of RWC of the polluted roadside area showed tolerance to vehicular air pollution.

Results revealed that some of the plant species of the polluted site showed a $\mathrm{pH}$ in acidic nature and some towards basic nature. The $\mathrm{pH}$ found maximum $6.70 \pm 0.0$ in Bahunia variegata and minimum in Tamarindus indica $2.9 \pm 0.0$ at polluted area roadside plants. The leaf extract $\mathrm{pH}$ plays a major role in regulating the $\mathrm{SO}_{2}$ sensitivity of plants. Researchers have reported that in the presence of an acidic pollutant, the leaf $\mathrm{pH}$ lowered and the decline is greater in sensitive species [33, 34]. Low leaf $\mathrm{pH}$ extract showed good correlation with sensitivity to air pollution and reduced photosynthetic process in plants [35]. The plants with high sensitivity to $\mathrm{SO}_{2}$ and $\mathrm{NO}_{2}$ closed the stomata faster when they exposed to pollutants [36].

The result of this study reveals that different trees respond differently to air pollution, hence have different indices. The study shows that the control site has more APTI than the polluted site. The APTI observed minimum in Tectona grandis $5.2 \pm 0.3247$ and maximum in Azadirachta indica $13.5 \pm 0.4404$. Reduction in APTI found the minimum for Alstonia scholaris (6.6\%), followed by Tamarindus indica (8.8\%) and Azadirachta indica (10.3\%). Reduction in APTI observed maximum for Tectona grandis (47.5\%), followed by Acacia nilotica (27.4\%) and Cassia fistula (20.7\%). From the result obtained, it revealed that Alstonia scholaris, Tamarindus indica, and Azadirachta indica found most tolerant since they had the least percentage reduction in APTI values. While Tectona grandis, Acacia nilotica, and Cassia fistula found more sensitive as they had the higher percentage reduction in APTI values.

However, some of the researchers found higher APTI values in the polluted environment as compared to the controlled environment [37]. This could be due to different environmental conditions. Moreover, the sensitivity of a plant species varies from area to area as they behave different atmospheric conditions [38] could be a reason. The study supports the results which other researchers also found that Azadirachta indica, as an intermediately tolerant and Tectona grandis as sensitive species towards air pollution. [39, 40].

Between the ten plants species considered for experimental analysis, the order of plant species tolerant to air pollution with the percentage change in APTI values is as follows: 
Alstonia scholaris (6.6\%)>Tamarindus indica (8.8\%)>Azadirachta indica (10.3\%)>Moringa pterygosperma (11.9\%)>Mangifera indica (13.9\%) $>$ Bahunia variegate (14.3\%) $>$ Annona squamosa (18.7\%)>Cassia fistula (20.7\%)>Acacia nilotica (27.4\%)>Tectona grandis (45.5\%)

Tolerant plant species can be used in Greenbelt development, as they tend to serve as barriers and act as a sink for air pollutants. These plant species can play a significant role along the city roadside, traffic islands as well as in industrial areas to control the level of air pollution, while sensitive plant species can act as bioindicators of air pollution. These particular plant species help to mitigate environmental air pollution.

\section{Correlation matrix interpretation}

The correlation coefficient values of biochemical parameters viz., total chlorophyll, ascorbic acid, relative water content, and leaf extract $\mathrm{pH}$ with air pollution tolerance index of selected plant species are presented in table 2, and 3. At control as well as polluted sites, APTI showed a positive correlation with $\mathrm{pH}, \mathrm{RWC}$, and Ascorbic acid but negative correlation with total chlorophyll. It is revealed from the study that ascorbic acid content and RWC are the most significant factors of the leaves, which determines the tolerance of same species at different locations.

\section{CONCLUSION}

The results of the present study provide information that the vehicular pollution of the Thane city is creating trouble not for all organisms but also for the plants. Plants in urban areas are continuously exposed to air pollutants, ensuing accumulation of pollutants and their integration into their system, resulting in changing the nature of leaf and its tolerance and sensitivity. This sensitivity is measured through various biochemical parameters and finally through APTI. Since this, determination of APTI is more appropriate than before. The plant that shows higher index value is tolerant to air pollution and can be used as a sink to control pollution. The plants with lower index value seemed to be sensitive and used as bioindicator to recognise levels of air pollution. Thus, trees can utilize as tolerant or sensitive towards air pollution.

Air pollution in the urban region is on the rise and augmented significantly due to increased vehicular pollution, urbanization and fast increase in small-scale industries. Existing quantity of air quality improvement due to pollution removal from urban trees is although insignificant, it can improve by improving urban tree canopy cover via Greenbelt development and urban forest development initiatives. Thus, this study provides useful insights for selecting tolerant and sensitive species for future planning and Greenbelt development in urban areas.

\section{ACKNOWLEDGEMENT}

Authors are thankful to The Director, The Institute of Science, Fort, Mumbai-32 (India) for providing assistance in carrying out the study.

\section{AUTHOR CONTRIBUTION}

These authors contributed equally to this work

\section{CONFLICTS OF INTERESTS}

All authors have none to declare

\section{REFERENCES}

1. Hamraz HA, Sadeghi-Niaraki, Omati M, Noori N. GIS-based air pollution monitoring using static stations and mobile sensor in Tehran/Iran. Int J Sci Res Environ Sci 2014;2:435-48.

2. Khureshi SGD. Air pollution tolerance indices (APTI) of some plants around Ponnur, Guntur (Dist.). Int J Eng Res Tech 2013;2:2366-75.

3. Feder WA. Plants as bioassay systems for monitoring atmospheric pollutants. Environ Health Perspect 1978;27:139-47.

4. Hasegawa YH, Uchida S, Asada T, Katsube, Oyabu T. Investigation of air pollution purification process by a bioelectrical potential analysis. Proceedings Indoor Air Health Prospect 2002;27:139-47.
5. Simon E, Simini M, DecoTeau DR. Using plants to monitor air pollution: Purdue Univ West Lafayette, Indiana; 2006. p. 47907.

6. Chauhan A. Photosynthetic pigment changes in some selected trees induced by automobile exhaust in Dehradun, Uttarakhand. J New York Sci 2010;3:45-51.

7. Dohmen GP, Loppers A, Langebartels C. Biochemical response of Norway spruce towards 14 mo exposure to ozone and acidmist, the effect on an amino acid, glutathione and polyamine titers. Environ Pollut 1990;64:375-83.

8. Hoque MA, Banu MNA, Oluma E. Exogenous proline and glycine betaine increase $\mathrm{NaCl}$-induced ascorbate-glythione cycleenzyme activities and praline improves salt tolerances more than glycine betaine in tobacco bright yellow-2 suspension cultural cells. J Plant Physiol 2007;164:1457-68.

9. Flowers MD, Fiscus EL, Burkey KO. Photosynthesis, chlorophyll fluorescence and yield of snap bean (Phaseolus vulgaris L.) genotypes differing in sensitivity to ozone. Environ Exp Bot 2007;61:190-8.

10. Klumpp G, Furlan CM, Domingos M. Response of stress indicators and growth parameters of Tibuchina Pulchra Cogn exposed to air and soil pollution near the industrial complex of Cubatao, Brazil. Sci Total Environ 2000;246:79-91.

11. Rao DN. Plant as a pollution-monitoring device. Fertilizer News 1979;24:26-8.

12. Kotecha MK, Naik, Abraham L. Study of the air pollution tolerable index (APTI) and distribution pattern by using importance value index (IVI) of plants in the disturbed and undisturbed locality around Anand city (India). Carpathian J Earth Environ Sci 2014;9:163-9.

13. Vinita P, Tripathi BD, Mishra VK. Evaluation of anticipated performance index of some tree species for green belt development to mitigate traffic generated noise. Urban Forestry Urban Greening 2011;10:61-6.

14. Cooke T. The flora of the presidency of Bombay. Vol. 1, 2, 3. London: Taylor and Francis; 1908.

15. Arnon DI. Copper enzymes in isolated chloroplast polyphenol oxidase in Beta vulgaris. Plant Physiol 1949;24:1-15.

16. Barr HD, Weatherley PE. A re-examination of the relative turgidity technique for estimating water deficits in leaves. Aust J Biol Sci 1962;15:413-28.

17. Bajaj KL, Kaur G. Spectrophotometric determination of l-ascorbic acid in vegetables and fruits. Analyst 1981;106:117-20.

18. Singh SK, Rao DN. Evaluation of plants for their tolerance to air pollution. Proceedings Int Symp on air pollution control IIT Delhi; 1983. p. 218-24.

19. Seyyednjad SM. Air pollution tolerance indices of some plants around the industrial zone in the south of Iran. Asian J Biol Sci 2011;4:300-5.

20. Katiyar V, Dubey PS. Sulphur dioxide sensitivity on two stage of leaf development in few tropical tree species. Indian J Environ Toxicol 2001;11:78-81.

21. Ninave SY, Chaudhari PR, Gajghate DG, Tarar JL. Foliar biochemical features of the plant as indicators of air pollution. Bull Environ Contan Toxicol 2001;67:133-40.

22. Anthony P. Dust from walking tracks, impact on rainforest leaves on epiphylls. Co-operative Res Center for Tropical Rainforest Eco and Manage, Australia; 2001.

23. Tripathi AK, Gautam M. Biochemical parameters of plants as indicators of air pollution. J Environ Biol 2007;28:127-32.

24. Mir QA, Yazdani T, Kumar A, Narain K, Yunus M. Vehicular population and pigment content of certain avenue trees. Pollut Res 2008;27:59-63.

25. Keller T, Schwager H. Air pollution and ascorbic acid. Eur J For Pathol 1977;7:338-50.

26. Conklin PL. Recent advances in the role and biosynthesis of ascorbic acid in plants. Plant Cell Environ 2001;24:383-94.

27. Pasqualini S, Batini P, Ederli L. Effects of short-term ozone fumigation on tobacco plants: Response of the scavenging system and expression of the glutathione reductase. Plant Cell Environ 2001;24:245-52.

28. Chaudhary CS, Rao DN. Study of some factors in plants controlling their susceptibility to sulphur dioxide pollution. Proceedings Indian Natl Sci Academy-Part B 1977;46:236-41. 
29. Varshney SRK, Varshney CK. Effects of sulphur dioxide on ascorbic acid in crop plants. Environ Pollut 1984;35:28590.

30. Masuch G, Kicinski HC, Kettrup A, Boss KS. Single and combined effects of continuous and discontinuous $\mathrm{O}_{3}$ and $\mathrm{SO}_{2}$ emission on Norway spruce needles. Historical and cytological changes. Int J Environ Anal Chem 1998;32:213-41.

31. Agrawal S, Tiwari SL. Susceptibility level of few plants on the basis of air pollution tolerance Index. Indian For 1997;123:319-22.

32. Dedio W. Water relations in wheat leaves as screening tests for drought resistance. Canad J Pt Sci 1975;55:369-78.

33. Rao DN. Use of plants as indicators and monitors of $\mathrm{SO}_{2}$ pollution. Chem Age India 1977;28:665-72.

34. Scholz F, Reck S. Effects of acids on forest trees as measured by titration invitro inheritance of buffering capacity in Picea-abies. Water, Air Soil Pollut 1977;8:41-5.

35. Yan Ju L, Hui D. Variation in air pollution tolerance index of the plant near a steel factory; Implication for landscape plant species selection for industrial areas. WSEAS Trans Environ Dev 2008;1:24-32.
36. Thambavani S, Prathipa DV. Assessment of air quality through biomonitors of selected sites of dindigul town by air pollution tolerance index approach. J Res Biol 2012;2:193-9.

37. Agbaire PO, Esiefarienrhe E. Air pollution tolerance indices (APTI) of some plants around otorogun gas plant in Delta state, Nigeria. J Applied Sci Environ Manage 2009;13:11-4.

38. Raza SH, Murthy MSR, Ahmed A. Air pollution tolerance index of certain plants of Nacharam Industrial Area, Hyderabad. Indian J Bot 1988;11:91-5.

39. Krishnaveni M, Durairaj S, Madhiyan $P$, Amsavalli L, Chandrasekar R. Impact of air pollution in plants near the thermal power plant, Mettur, Salem, Tamilnadu, India. Int J Pharm Sci Rev Res 2013;20:173-7.

40. Krishnaveni M, Mangesh P. Air pollution tolerance index induced by biochemical components in plants. Int J Pharm Pharm Sci 2014;6:362-4.

\section{How to cite this article}

- $\quad$ Aasawari A Tak, Umesh B Kakde. Assessment of air pollution tolerance index of plants a comparative study. Int J Pharm Pharm Sci 2017;9(7):83-89. 